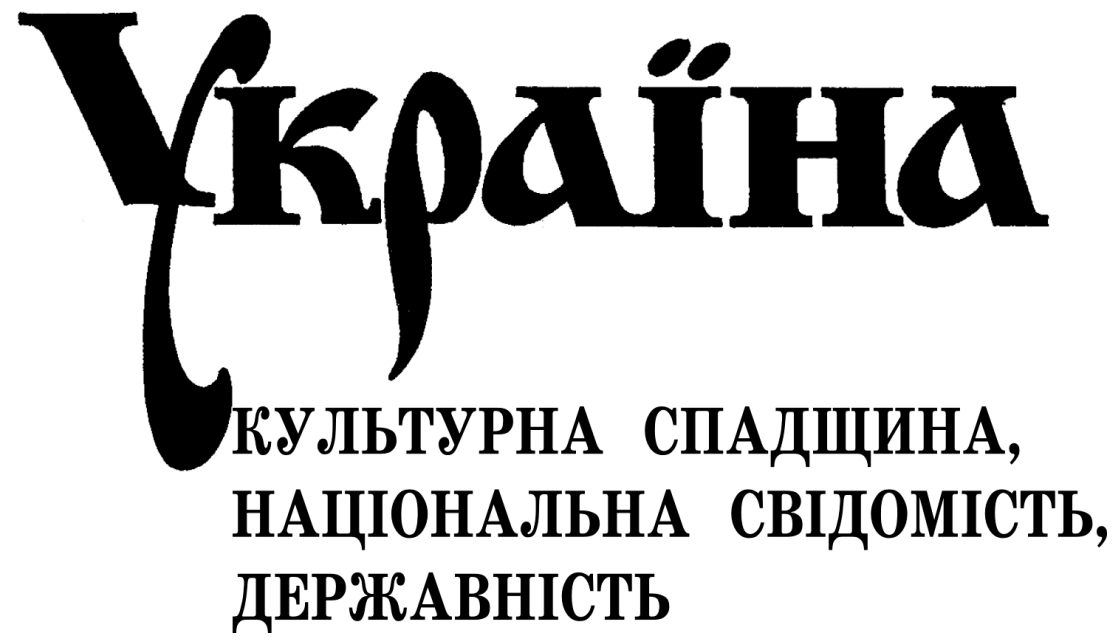

$\frac{2018}{31}$

ЛЬВІВ

त्रा 2018 
Україна: культурна спадщина, національна свідомість, державність / гол. ред. Ігор Соляр; НАН України, Інститут українознавства ім. І. Крип’якевича. Львів, 2018. Вип. 31. $308 \mathrm{c}$.

Збірник об'єднує студії з історії, мовознавства та літературознавства.

В історичному блоці представлені наукові дослідження різних аспектів актуальних проблем історії, зокрема Західноукраїнської Народної Республіки, воєнної історії, а також про відомих людей та їх значення у формуванні української державності.

Мовознавчі студії розкривають проблеми історії української філології (явища староукраїнської мови XVI-XVIII ст., дослідження пам'яток) і діалектології (діалектної лексикографіï).

Наукові публікації з літературознавства зосереджені довкола аналізу праць міжвоєнного періоду (Софія Яблонська-Уден, Михайло Рудницький) і відображають проблеми воєнного часу в сучасних текстах.

Ukraine: Cultural Heritage, National Consciousness, Statehood / Ed. Ihor Soliar; NAS of Ukraine, I. Krypiakevych Institute of Ukrainian Studies. Lviv, 2018. Vol. 31. 308 p.

The collection of scientific papers is an interdisciplinary edition of the Institute, which integrates studies in history, linguistics, and literary criticism.

The historical block is represented by studies of current problems of history, such as the history of the West Ukrainian People's Republic, military history, as well as investigations about famous persons and their importance in the formation of Ukrainian history.

Linguistic studies reveal issues in the history of Ukrainian language (phenomena in the Old Ukrainian language of the 16th-18th centuries, studies of monuments), and dialectology (dialectal lexicography).

Literary criticism studies focus on the analysis of works of the interwar period (Sofiia Yablonska-Uden, Mykhailo Rudnytskyi), and reflect the problems of wartime in contemporary texts.

Рекомендувала до друку вчена рада

Інституту українознавства ім. І. Крип’якевича НАН України

(протокол № 4 від 11.12.2018 р.)

ГОЛОВНИЙ РЕДАКТОР

Соляр Ігор Ярославович, д.і.н., с.н.с. (Україна)

РЕДАКЦІЙНА КОЛЕГІЯ:

Акіллі Алессандро (Achilli Alessandro), $\mathrm{PhD}$ (Australia)

Борчук Степан Миколайович, д.і.н., проф. (Україна)

Газдаг Вільмош (Gazdag Vilmos), PhD (Україна)

Даниленко Андрій (Danylenko Andriy), PhD, prof. (США)

Золтан Андраш (Zoltán András), dr hab., prof. (Угорщина)

Литвин Микола Романович, д.і.н., проф. (Україна)

Мозер Міхаель (Moser Michael), dr hab., prof. (Австрія)

Муравський Олег Іванович, к.і.н., с.н.с. (Україна)

Надрага Марта Степанівна, к.і.н., с.д. (Україна)

Пастух Тарас Васильович, д.філол.н., доц. (Україна)

Рембішевська Дорота Кристина (Rembiszewska Dorota Krystyna), dr hab., prof. (Польща)

Романюк Михайло Васильович, к.і.н. (Україна)

Ситник Олександр Степанович, д.і.н., проф. (Україна)

Ястремська Тетяна Олександрівна, к.філол.н., с.н.с. (Україна) 
УДК [94:35.075.51:002.2](477.8)»1918/1919»

DOI: $10.33402 / \mathrm{ukr} .2018-31-79-87$

\section{Марія ПІРКО}

аспірант кафедри історичного краєзнавства Львівського національного університету ім. І. Франка ORCID: https://orcid.org/0000-0001-6028-0153 e-mail: mariya.pirko@gmail.com

\section{ВИДАВНИЧІ ПРОЕКТИ ДЕРЖАВНОГО СЕКРЕТАРІАТУ ЗУНР}

На основі друкованої продукції уряду Західноукраїнської Народної Республіки (ЗУНР) висвітлено особливості видавничих проектів, які відображали державотворчу, політичну, законодавчу й організаційну роботу Державного секретаріату. Схарактеризовано їхній формат, зміст і тематичну спрямованість, вплив на формування національного світогляду населення та розвиток культурно-просвітницького руху в повоєнні роки. Видання Державного секретаріату поділено на три групи: офіційні (законопроекти), періодика, література - донині належно не описані в історіографії.

Ключові слова: ЗУНР, Державний секретаріат, Орест Кузьма, календарі-часословці, видавнича справа, національно-патріотична ідея.

Утворення Західноукраїнської Народної Республіки в листопаді 1918 р. було однією з головних подій національно-визвольних змагань українського народу після воєнних дій і розпаду Австро-Угорської монархії. Виконавчим органом стала Рада державних секретарів (Держаний секретаріат), члени якої розгорнули активну діяльність в умовах критичної політичної ситуації, коли ще не було створено ні боєздатної армії, ні дієвих місцевих органів державної влади, ні законодавства. 3 великою охотою вони бралися за працю на культурно-просвітній ниві, що дозволяла здобути підтримку населення.

Упродовж листопада 1918 р. і до липня 1919 р. стратегічними завданнями Державного секретаріату були: утвердження української державності, зміцнення iii позицій і пробудження свідомості населення краю. У нових політичних умовах інтелігенція хотіла забезпечити українського читача «корисною» інформацією. Демократизація суспільного життя сприяла поширенню свободи слова та друку. Як наслідок, з'явився десяток нових українських видань.

Історії ЗУНР присвячено чимало літератури, різнопланової за проблематикою, формою, жанром. Досить широко в загальних і фахових дослідженнях висвітлені особливості функціонування ії̈ української періодики. Матеріали преси як джерело подані в роботах дослідників того періоду С. Макарчука, М. Литвина, О. Карпенка, 
С. Горєвалова ${ }^{1}$, колективних монографіях ${ }^{2}$ тощо. Періодичні видання молодої держави, їхня кількість та тематична класифікація стали об'єктом вивчення Є. Місила, М. Васильчука, Л. Кобути, В. Великочия ${ }^{3}$ У роки незалежності України укладено каталоги, що відображають видавничу активність Державного секретаріату ${ }^{4}$

Однак, окрім газет і часописів, уряд та провідні діячі ЗУНР поширювали й друкували проекти законів, вісники департаментів, календарі та книжкову продукцію, яку практично не згадують науковці-журналісти, літератори, а тим паче історики.

Мета статті - проаналізувати особливості та змістове наповнення видавничих проектів Державного секретаріату, його членів і з'ясувати їхню роль у національному вихованні людності краю. Джерелом наукового дослідження стала друкована продукція уряду: законопроекти, календарі, співаники, брошури, видані у Станіславові (тепер Івано-Франківськ), Коломиї та ті, що зберігаються у фондах Львівської наукової бібліотеки ім. В. Стефаника (відділ україніки), бібліотеці Центрального державного історичного архіву у Львові.

До уряду ЗУНР увійшли провідні діячі західноукраїнських земель, які вже мали практичний досвід у видавничій справі. Головою Державного секретаріату обрали видатного політика, активного культурно-просвітнього діяча Костя Левицького. Міністром закордонних справ став головний редактор газети «Діло» Василь Панейко; міністром шкільництва та віросповідань - історик, педагог, член Крайової шкільної ради Олександр Барвінський; земельних справ - адвокат, головний редактор тижневика «Свобода» Степан Баран та ін. Відтак особливістю видавничої діяльності уряду ЗУНР стала безпосередня чи опосередкована участь представників влади в ролі редакторів, видавців, активних дописувачів тощо.

Зміна столиць ЗУНР: Львів (листопад 1918 р.), Тернопіль (листопад-грудень 1919 р.), Станіславів (січень-травень 1919 р.) призвела до переміщення центру видавничої практики Державного секретаріату зі Львова до повітових центрів. Очевидно, масштаби поширення друкованої продукції стали меншими, але це дозволило розширити горизонти культурно-просвітньої політики молодої держави. Уряд хотів здобути підтримку більшої кількості населення, розвивати національну школу не тільки у просвітньому центрі Галичини - Львові, а й виховувати

1 Макарчук С. Українська Республіка галичан: Нариси про ЗУНР. Львів, 1997. 191 с.; Литвин М., Науменко К. Історія ЗУНР. Львів, 1995. 368 с.; Західно-Українська Народна Республіка 19181923. Документи і матеріали: у 5-ти т. / уклад.: О. Карпенко, К. Мицан. Івано-Франківськ, 2001. T. 1.584 с.; Горєвалов С. Українське військо та його преса на завершальному етапі визвольних змагань (1919-1920рр.). Збірник праць Науково-дослідного центру періодики. Львів, 1998. Вип. V. С. 199-207.

2 Нариси історії Української революції 1917-1921 рр.: у 2-х кн. / авт. кол. В. Верстюк та ін. Київ, 2011. Кн. 1. 340 с.; Київ, 2012. Кн. 2. 462 с.

3 Місило Є. Бібліографія української преси в Польщі (1918-39) і Західно-Українській Народній Республіці (1918-1919 рр). Едмонд, 1991. 250 с.; Васильчук М. Українська видавнича справа в Коломиї (друга половина ХІХ-XX ст.). Коломия, 2012. 216 с.; Кобута Л. Пресові видання ЗУНР: специфіка функціонування та ідеологія змістового наповнення. Україна: культурна спадщина, наиіональна свідомість, державність. Львів, 2009. Вип. 18. С. 644-651; Великочий В. Джерела до вивчення державного будівництва в ЗУНР. Івано-Франківськ, 2003. 278 с.

4 Українська книга в Галичині, на Буковині, Закарпатті, Волині та в еміграції, 1914-1939: Бібліогр. покажчик / уклад. Л. Ільницька (кер. проекту), відп. ред. М. Романюк. Львів, 2010. T. 1: 1914-1919. 472 c. 
патріотизм молоді всюди. Тому видавнича діяльність була кроком до співпраці політичної еліти з народом, до взаєморозуміння та боротьби.

Загальна кількість друкованих видань ЗУНР упродовж жовтня 1918 р. - березня 1923 р. становила $110^{5}$ (за підрахунками вітчизняних учених - 40, діаспорний дослідник $Є$. Місило виділяє 63) періодичні видання ${ }^{6}$. Але, крім пресодруків, під егідою Державного секретаріату також вийшло ще інших 15 видань: розпорядники, календарі, навчальна й господарська література. Усю продукцію можна поділити на три групи:

1. офіційні видання (законопроекти);

2. українська періодика;

3. різна література.

Першим завдання виконавчого органу ЗУНР було створення законодавчої бази для існування новоутвореної держави. Тому серед видавничих проектів чільне місце займає офіційна документація. Сюди належать розпорядники, обіжники й інші нормативні акти, що не мали чіткої періодичності. Видавали їх у часі напрацювання та затвердження, вірили, що «покладуть перші основи державности молодої ЗахідньоУкраїнської Народньої Республіки» ${ }^{7}$. Державний секретаріат опублікував «Збірник законів, розпорядків та газет, обіжників...», «Вістник державних законів...», «Вістник Державного Секретаріяту військових справ», «Вістник Державного Секретаріяту освіти і віросповідань», «Вістник Державного Секретаріяту шляхів, почт і телеграфів». Уряд ЗУНР використовував не лише пресу для діалогу з народом, а й нормативно-законодавчі матеріали, ознайомлював суспільство зі структурою організації влади, векторами іï роботи, змінами внутрішньої політики. Видання окреслювали адміністративно-територіальний поділ на округи, специфіку роботи департаментів, їхню організаційну структуру тощо. Наприклад, за півроку у «Biстнику Державного Секретаріяту військових справ» (16 випусків) опублікували близько 60 розпорядків, які в основному підписував голова уряду К. Левицький (а від січня 1919 р. В. Голубович) і секретарі департаменту. На титульній сторінці видання зазначали, що «на правах рукопису», щоб не спричинити підозр галичан щодо невідповідності друкованого варіанта з оригіналом. Документи, опубліковані у збірниках, стосувалися військово-територіального адміністрування, військових кадрів, структури реорганізації військ, судівництва, жандармерії.

Потужним видавничим проектом були книги Окружної військової команди (ОВК) у Коломиї ${ }^{8}$ під управою педагога, перекладача, громадсько-культурного діяча Ореста Кузьми (від квітня 1919 р. - Антона Гринцишина). Великим його досягненням був випуск у 1913 р. першого українського періодичного видання

5 Західно-Українська Народна Республіка. 1918-1923: Історія / кер. авт. кол. О. Карпенко. ІваноФранківськ, 2001. С. 257.

6 Кобута Л. Пресові видання ЗУНР: специфіка функціонування та ідеологія змістового наповнення... С. 646.

7 Стебельський С., Чайковський Б. Проєкт закона про Установчий Сойм Західньої области Української Народньої Республики і виборчої ординації до Установчого Сойму Західньої Области Української Народньої Республики. Станиславів: Накладом авторів. Друкарня Льва Данкевича, 1919. С. 3.

8 Командантом ОВК у Коломиї був сотник Теодор Примак. 
мовою есперанто ${ }^{9}$ «Ukraine Stelo» («Зоря України»), який виходив до кінця червня 1914 р., і після тривалої перерви, спричиненої воєнними діями, у 1922-1930 рр. на його сторінках всупереч цензурі друкували переклади творів Т. Шевченка, I. Франка, О. Кобилянської, В. Стефаника, Лесі Українки, М. Коцюбинського, народні пісні, коломийки, статті про творчість українських письменників ${ }^{10}$. У роки Першої світової війни О. Кузьма пройшов тернистим бойовим шляхом Українських січових стрільців (УСС) у 3-й сотні Івана Коссака, а в період ЗУНР повернувся до видавничої практики. Талановитий галичанин вірив у силу друкованого слова, усвідомлював значення пропаганди української культури в ріднім краю та світі в умовах бездержавності.

Наприкінці 1918 р. ОВК у Коломиї відкрила власну друкарню з якісним обладнанням для продукції з ілюстраціями ${ }^{11}$. Це дозволило підняти рівень книго- та пресодруків, контролювати видавничу діяльність. Тут друкували не лише часописи («Січовий голос», «Покутський вістник»), брошури, а й календарі, художню, науково-популярну літературу та господарські книги. Оригінальний проект друкарні - невелика за обсягом і накладом брошура О. Кузьми «Ключ до читання жидівського друку». Це - допоміжний путівник мовою їдиш з українськими відповідними словами і транскрипцією польською мовою. Значно полегшувало читання брошури та самостійне опанування нової мови вступне слово. Ініціатором видання був не лише управитель друкарні української військової адміністрації, а й єврейські громадсько-політичні діячі краю ${ }^{12}$.

Одне з головних завдань державної політики ЗУНР - становлення національної школи. У листопаді 1918 р. створили Державний секретаріат освіти і віросповідань, який очолив Олександр Барвінський. До переліку справ, що розглядав департамент, належало й видання шкільних підручників, науково-популярної літератури. Проте реалізувати плани в царині літератури так і не вдалося.

Корисним видання для вивченням рідної мови була брошура О. Кузьми «Український правопис». У вступі автор наголошував, що до нього неодноразово «зверталися із запитами в справі українського правопису, якого вживають зараз в державнім урядуванню та часописях». А це підтверджує рішучі кроки уряду в освітній сфері: розбудові українського шкільництва, використання рідної мови в адміністративних установах, видання україномовної продукції. Брошура, невелика за обсягом, подає основні правила правопису, вживання слів чужоземного походження в «чисто з’українщенім виді», використання букви «Г» замість «г» в окремих словах, що, на думку О. Кузьми, найбільше відповідає «духови української нації» ${ }^{13}$.

9 Есперанто («той, що сподівається») - штучна мова, в основі якої лежить латинка і найпоширеніші європейські мови. Ї̈̈ творцем у 1887 р. був варшавський лікар-окуліст, поліглот Людвік Заменгоф. Ця мова проста за будовою (алфавіт нараховує 28 літер) і доступна для оволодіння широкими колами осіб.

${ }^{10}$ Кожерчук М. Засновник українського есперанто в Галичині - Орест Кузьма. Коломия ВЕБ портал. URL: http://kolomyya.org/histpub/historypub38.htm.

${ }^{11}$ Васильчук М. Українська видавнича справа... С. 58.

${ }^{12}$ Монолатій I. До початків українсько-єврейського діалогу на Покутті у контексті становлення ЗУНР. Коломия ВЕБ портал. URL: http://kolomyya.org/histpub/historypub3.htm.

13 Український правопис: Зібрав і до приватнього вжитку приладив Орест Кузьма. 2-ге вид. Коломия: Накладом автора, 1919. С. 2. 
Опікувався уряд й розбудовою народного господарства - фундаменту економічного розвитку молодої держави. У пресових виданнях публікували багато заміток сільськогосподарського змісту. Крім того, досвід читалень «Просвіти» показав, що селяни й частина міщан цікавляться економічною та господарською літературою, новинками, які можна легко застосувати в повсякденному житті, реальними історіями з організації власного виробництва тощо.

За сприянням і накладом Державного секретаріату військових справ (ДСВС) опубліковано брошуру з ветеринарії «Пархи у коней і спосіб їх лїчення» та 3 ініціативи комісара м. Коломиї, голови Української Національної Ради (УНРади) Коломийського повіту Захарія Скварка - книги «Земельна справа» та «Початкова наука про народне (суспільне) господарство». У них вміщено коротку історію розвитку світового й українського господарства, подано порівняльну характеристику земельних відносин у Галичині та Великій Україні, опубліковано закони про землю. Але історичний контекст, теорія і складна термінологія стали малоефективними для реального господарювання. Мабуть-таки, ці книжечки не особливо зацікавили галичан.

До третьої групи видавничої практики Державного секретаріату належать календарі, які завжди були популярними. Серед них «Український жовнір», «Січова зоря», «Січова зірниця» (зменшений варіант «Січової зорі»), «Українець». Зміст й тематика видань були подібними. «Ілюстровані українські часословці» складалися iз річного календаря християнських свят, гімну «Вже воскресла Україна», патріотичних, сокільських або стрілецьких пісень і літературної або історичної частини. Остання складова в кожному календарі відрізнялася. Наприклад, у часослові «Український жовнір» розміщено інформацію про військово-територіальний поділ земель Української держави, структуру війська (чета, сотня), польову пошту, поведінку під час бою, вкінці - замітка Богдана Лепкого «Український край і народ», яку доповнює карта «Україна та ії сусіди». Натомість «Січова зоря» закінчується короткою розповіддю Прокопа Рибчука про Україну, в якій автор пояснює значення національних символів (герба, гімну), патріотичних пісень й ознайомлює читачів із козацько-гетьманською добою. Метою патріотичних текстів (автори: П. Чубинський, М. Вербицький, П. Рибчук, І. Франко, К. Устиянович та ін.) було не загострити суперечності між представниками різних національностей, налаштувати українську спільноту проти поляків, євреїв тощо, а навпаки, пояснити заради чого ведеться боротьба, звернути увагу на мирні законні взаємини та «по справедливости» розподілити території: «Один нарід над другим не повинен панувати. ... По доброму можемо їм дати і нафти, і збіжа, і всего - як доброму сусідови. Але рабунком на нас іти - на се український жовнір не позволить» ${ }^{14}$.

Календарі висвітлювали суспільно-політичне та культурне життя українців, ознайомлювали читачів з історією (особливо Запорозької Січі та козацької доби), біографіями українських гетьманів (Богдана Хмельницького, Івана Мазепи), політичних і культурних діячів (Михайла Грушевського). Наголошували редактори на традиції українського державотворення ще від Володимира Великого, виховували покоління патріотів та свідомих громадян серед усіх прошарків суспільства.

${ }^{14}$ Приятель Жовніра: Збірник найкращих пісень січових, стрілецьких і народних. Коломия: Накладом Івана Чупрея, 1919. С. 2 обкл. 
Відповідно, зміст календарів визначав читацьку аудиторію - «для вжитку і науки української молоді і старших» ${ }^{15}$.

Особливого значення у внутрішній політиці Державного секретаріату набувала проблема міжнаціональних взаємин. Постанова УНРади від 19 жовтня 1918 р. визнавала євреїв окремою нацією, за ними визнано всі права національної меншини ${ }^{16}$. Проте питання вирішували не лише на законодавчому рівні, а й у сфері освіти та видавничій справі - календарна частина у всіх часословцях закінчувалася «жидівським калєндарем» (єврейським). А це підтверджує акцент уряду на рівноправності всіх націй, демократизмі, поміркованій національній політиці та державній зрілості української громадськості.

Заслуговує уваги збірник січових, стрілецьких і народних пісень «Приятель жовніра», виданий за ініціативи культурно-освітнього діяча, січового поета Івана Чупрея ${ }^{17}$. Книжечка складається з 21-ї патріотичної пісні: «Ми гайдамаки», «Поставали козаченьки», «Ой у лузі червона калина...», «Гей, там на горі Січ іде...», «Засвистали козаченьки», «Їхав стрілець на війноньку...», «Гей, ви хлопці січовії» та ін. Видання розпочинає «Боєва пісня»- уривок із «дотеперішнього» ${ }^{18}$ українського гімну «Ще не вмерла Україна». Народні композиції доповнили авторські пісні Івана Франка «Розвивайся ти високий дубе», «Гимн руських хлопів радикалів» $\mathrm{i}$ Віри Лебедової «Січовий поклик».

Збірничок «Приятель жовніра» став актуальним виданням у роки ЗУНР, адже у складних політичних обставинах, при постійній військовій напрузі народні пісні залишали помітний слід у серцях галичан, розбавляли сірі будні селян, додавали наснаги воїнам. А зручний формат - невеликий розмір, обсяг й тверда обкладинка - дозволяли тримати його весь час під рукою ${ }^{19}$. Справедливо зазначити, що галицькі видавці нечасто друкували подібні збірки творів або фольклору. Практично, впродовж 1918-1919 рр. поодинокі народні пісні публікували на сторінках календарів просвітніх організацій та у «Літописі Червоної Калини» однойменного видавничого кооперативу у Львові.

Зрозуміло, в умовах важкої польсько-української війни потрібна була серйозна публіцистична література, спрямована проти галасливої польської кампанії, покликаної мотивувати Галицьку армію. 3 власної ініціативи повітовий комісар ЗУНР у Самборі Андрій Чайковський, відомий письменник і громадський діяч, адвокат, весною 1919 р. накладом 3000 примірників видав свою брошуру «До українських воїнів моє

${ }^{15}$ Січова Зірниця: Підручний часословець на 1919 рік. Коломия: Друкарня ОВК під управою О. Кузьми в Коломиї, 1919. С. 1.

16 Західно-Українська Народна Республіка. 1918-1923: Історія... С. 229.

${ }^{17}$ Іван Чупрей - громадсько-політичний, культурно-освітній діяч, поет, публіцист, видавець, етнограф; засновник українського молодіжного пожежно-руханкового товариства «Січ» та його філій по селах Коломийщини. У роки Першої світової війни Чупрей був секретарем Крайового січового комітету, згодом - одним із організаторів бойової управи Січового стрілецтва, старшина УГА.

18 Автор пісенного збірника вживає слово «дотеперішній» до слів «Ще не вмерла Україна», щоб наголосити на частішому виконанні «Вже воскресла Україна» в роки ЗУНР.

19 Збірник пісень «Приятель жовніра» перевидала племінниця автора Орися Якуб'як у Коломиї в 2012 р. У сучасному виданні зберегли зміст оригіналу 1919 р., але його формат вже не такий зручний. Новий «Приятель жовніра» доповнили зображенням Івана Чупрея та світлинами 3 життя товариства «Січ» у Коломиї. 
дружнє послання». Вона, як справедливо твердив Б. Якимович, популярно пояснює українським військовим, чому ми боремося за визволення своєї землі, сповнена віри в українські збройні сили - такий публіцистичний твір актуальний і донині ${ }^{20}$.

Принагідно треба відзначити, що в багатьох виданнях Державного секретаріату національний гімн починається словами «Вже воскресла Україна» замість традиційних «Ще не вмерла Україна». Незвичну редакцію пісні від 1917 р. широко використовували політичні, громадські діячі, культурно-просвітні товариства, музичні колективи. 3 березня 1918 р. на честь проголошення самостійності Української Народної Республіки (УНР) і підписання Берестейського миру відбулася маніфестація у Станіславові. Урочисте святкування закінчили радісним співом «Вже воскресла» ${ }^{21}$. Слова «Вже воскресла Україна» 19 жовтня 1918 р. виконували повноважні представники галицьких і буковинських українців на установчому засіданні УНРади в Народному домі у Львові ${ }^{22}$. Під звуки нового гімну проходили численні народні віча ЗУНР. Про одне з них писала газета «Покутський вістник»: «На день 4 мая скликала Окружна Національна Рада в Коломиї віче, на яке прибули делегати 3 цілого Покуття. Всіх учасників було около 10 тисяч. Віче присвячене було виключно справі нашої оборони та скріпленню фронту. Перед отворенням віча відіграла оркестра зелизничників гимн «Вже Воскресла Україна!»») ${ }^{23}$. Подібних свідчень про використання змінених перших рядків гімну десятки, але так і невідомо, чия це була ініціатива: народна чи політиків. Ймовірно, ідеєю Василя Смеця, члена «Просвіти», диригента музичного колективу «Капела кобзарів», що одним із перших заспівав гімн зі змінами ${ }^{24}$. Але хто б це не зробив, вони, як і Державний секретаріат, добре розуміли важливість пісні як національного та консолідаційного символу. На думку дослідників - істориків, літераторів, соціологів і навіть психологів - заперечення у першому рядку Державного славня нівелює ідею єдності українських земель і народу, а слова «Вже воскресла Україна» підтверджують «воскресіння» нації, традиції державотворення, консолідації українців обох берегів Дніпра.

Детальної інформації про тиражі видавничих проектів Державного секретаріату немає. Ініціаторами й упорядниками були члени уряду, провідні діячі краю. Більшість накладів авторські, тому невеликі, але водночас вони задовольняли потреби й інтерес читачів. Про це свідчать повторні тиражі календарів. Так, часослов на 1919 р. забрали $з$ друкарні 28 грудня 1918 р., а 15 січня 1919 р. редакція на чолі з Прокопом Рибчуком готувала новий календар. Виручені кошти від продажу більшості друкованої продукції йшли на «підмогу батькам і матерям, вдовам та сиротам по Українських Січових Стрільцях, що поклали свої буйні голови у защиті України і коло виборення свободи і волі українського народа» ${ }^{25}$. На невеликі

\footnotetext{
20 Якимович Б. Андрій Чайковський: життя, творчість, громадська діяльність та державницьковійськова ідея. Україна та украӥнці: подї̈ далекі і близькі. Вибрані праці. Львів, 2014. С. 760 761.

${ }^{21}$ Станіславів у часи Західно-Української Народної Республіки. Документальні свідчення, спогади, оголошення, накази революційної доби / упоряд. І. Монолатій. Івано-Франківськ, 2008. C. 12.

${ }_{22}$ Старик В. Між націоналізмом і толерантністю. Чернівці, 2009. С. 11.

${ }^{23}$ Там само. С. 13.

${ }^{24}$ Там само. С. 11.

${ }^{25}$ Січова Зоря: Ілюстрований український часослов на 1919 рік. Коломия: 3 друкарні Окружної Військової Команди під управою О. Кузьми, 1919. С. 1.
} 
наклади й обсяг впливала ціна паперу та друку, про що неодноразово згадували автори чи укладачі.

Отже, як виконавчий орган, Державний секретаріат вміло реалізовував завдання: розробляв нові законопроекти, здійснював культурну, освітню політику, провадив видавничу діяльність, інформував населення щодо важливих соціально-політичних змін тощо. Зрозуміло, в умовах політичної неоднорідності уряду, економічної та соціальної розрухи, військового протистояння, розповсюдження друкованої продукції було нерегулярним, часто мало незначні наклади й обмежену читацьку аудиторію. Видавничі проекти уряду ЗУНР (особливо третя група), з одного боку, були чітко підпорядковані ухвалам представників владних структур, висвітлювали актуальну, на їхню думку, інформацію для населення, забезпечували народну підтримку владі. А з другого - це не політично-заангажовані видання, а цікава для селян, міщан, воїнів, інтелігенції продукція рідною мовою, що впливала на популяризацію місцевих виробників, установ, видавництв, культурно-просвітній розвиток. Вони забезпечували консолідацію народних мас, поширення національно-патріотичних ідей, традицій державотворення на принципах демократизму і національної толерантності.

\section{REFERENCES}

1. Chupreia, I. (1919). Pryiatel Zhovnira: Zbirnyk naikrashchykh pisen sichovykh, striletskykh i narodnykh. Kolomyia. [in Ukrainian].

2. Gorievalov, S. (1998). Ukrainske viisko ta ioho presa na zavershalnomu etapi vyzvolnykch zmahan (1919-1920 rr.). Zbirnyk prats Naukovo-doslidnoho centru periodyky, V, 199-207. [in Ukrainian].

3. Ilnytska, L. (Comp.). (2010). Ukrainska knyha v Halychyni, na Bukovyni, Zakarpatti, Volyni ta v emihracii, 1914-1939: Bibliohr. pokazhchyk. (Vol. 1). Lviv: NAN Ukrainy, LNNB Ukrainy im. V. Stefanyka. [in Ukrainian].

4. Karpenko, O. (Ed.). (2001). Zakhidno-Ukrainska Narodna Respublika. 1918-1923: Istoriia. Ivano-Frankivsk: Siversiia. [in Ukrainian].

5. Karpenko, O., \& Mytsan, K. (Comps.). (2001). Zakhidno-Ukrainska Narodna Respublika 1918-1923. Dokumenty i materialy (Vol. 1). Ivano-Frankivsk. [in Ukrainian].

6. Kobuta, L. (2009). Presovi vydannia ZUNR: spetsyfika funktsionuvannia ta ideolohiia zmistovoho napovnennia. Ukraina: kulturna spadshchyna, natsionalna svidomist, derzhavnist, (18), 644-651. Retrieved from: http://dspace.nbuv.gov.ua [in Ukrainian].

7. Kozherchuk, M. Zasnovnyk ukrainskoho esperanto v Halychyni - Orest Kuzma. Kolomyia VEB portal. Retrieved from: http://kolomyya.org/histpub/historypub38. htm [in Ukrainian].

8. Kuzma, O. (Comp.). (1919). Ukrainskyi pravopys: Zibrav i do pryvatnoho vzhytku pryladyv Orest Kuzma. (2nd rev. ed.). Kolomyia. [in Ukrainian].

9. Lytvyn, M., \& Naumenko, K. (1995). Istoriia ZUNR. Lviv. [in Ukrainian].

10. Makarchuk, S. (1997). Ukrainska Respublika halychan: Narysy pro ZUNR. Lviv. [in Ukrainian].

11. Misylo, Ye. (1991). Bibliohrafiia ukrainskoi presy v Polshchi (1918-39) i ZakhidnoUkrainskii Narodnii Respublitsi (1918-1919 rr). Edmond. [in Ukrainian]. 
12. Monolatii, I. (Comp.). (2008). Stanyslaviv u chasy Zakhidno-Ukrainskoi Narodnoi Respubliky. Dokumentalni svidchennia, spohady, oholoshennia, nakazy revoliuciinoi doby. Ivano-Frankivsk: Lileia-NV. [in Ukrainian].

13. Monolatii, I. Do pochatkiv ukrainsko-ievreiskoho dialohu na Pokutti u konteksti stanovlennia ZUNR. Kolomyia VEB portal. Retrieved from: http://kolomyya.org/ histpub/historypub3.htm [in Ukrainian].

14. Sichova Zirnytsia: Pidruchnyi chasoslovets na 1919 rik. (1919). Kolomyia: Drukarnia OVK pid upravoiu O. Kuzmy v Kolomyi. [in Ukrainian].

15. Sichova Zoria: Iliustrovanyi ukrainskyi chasoslov na 1919 rik. (1919). Kolomyia: Z drukarni Okruzhnoi Viiskovoi Komandy pid upravoiu O. Kuzmy. [in Ukrainian].

16. Staryk, V. (2009). Mizh natsionalizmom i tolerantnistiu. Chernivtsi: Vyd-vo «Prut». [in Ukrainian].

17. Stebelskyi, S., \& Chaikovskyi, B. (1919). Proiekt zakona pro Ustanovchyi Soim Zakhidnoi oblasty Ukrainskoi Narodnoi Respublyky i vyborchoi ordynatsii do Ustanovchoho Soimu Zakhidnoi Oblasty Ukrainskoi Narodnoi Respublyky. Stanyslaviv: Drukarnia Lva Dankevycha. [in Ukrainian].

18. Vasylchuk, M. (2012). Ukrainska vydavnycha sprava v Kolomyi (druha polovyna $X I X-X X$ st.). Kolomyia: Vik. [in Ukrainian].

19. Velykochii, V. (2003). Dzherela do vyvchennia derzhavnoho budivnytstva $v$ ZUNR. Ivano-Frankivsk: Plai. [in Ukrainian].

20. Verstiuk, V. (Ed.). (2011). Narysy istorii Ukrainskoi revoliucii 1917-1921 rr. (Vol. 1). Kyiv: Naukova dumka. [in Ukrainian].

21. Verstiuk, V. (Ed.). (2012). Narysy istorii Ukrainskoi revoliucii 1917-1921 rr. (Vol. 2). Kyiv: Naukova dumka. [in Ukrainian].

22. Yakymovych, B. (2014). Andrii Chaikovskyi: zhyttia, tvorchist, hromadska diialnist ta derzhavnytsko-viiskova ideia. In B. Yakymovych (Ed.), Ukraina ta ukraintsi: podii daleki i blyzki. Vybrani pratsi (pp. 753-761). Lviv. [in Ukrainian].

\section{Mariia PIRKO}

PUBLISHING PROJECTS OF THE STATE SECRETARIAT OF THE WEST UKRAINIAN PEOPLE'S REPUBLIC

This article analyzes the specifics of publishing projects of the Government of the West Ukrainian People's Republic. These projects represented the state-building, political, legislative and organizational work of the State Secretariat. Publishing products were irregular and often had little circulation as well as limited amount of readers, because they were printed in the conditions of political divergence of the government, economic and social difficulties, and military confrontation. The publications of the State Secretariat were divided into three groups: official publications (bills), Ukrainian periodicals (magazines), various literature (calendars, books of songs, sociopolitical issues), which until now have not been properly highlighted in historiography. The author characterized format, content, and thematic orientation of the editions as well as their impact on the formation of the national outlook of the Ukrainian people and the development of the cultural and educational movement in post-war time.

Keywords: West Ukrainian People's Republic, State Secretariat, publishing, Orest Kuzma, calendars, national-patriotic idea. 


\section{MICT}

\section{ІСТОРИЧНІ СТУДІї}

Актуальні питання української історії ........................

Мисак Наталія. Ідеї соборності та самостійності

в українському молодіжному середовищі Галичини

наприкінці XIX - початку XX століття. . . . . . . . . . . . . . . 3

Фіногенов Олег. «Ліонський сюжет» (1924)

у діяльності Західноукраїнського товариства Ліги Націй. . . . . . . . . . 16

Стасюк Олександра. Роль рад депутатів трудящих у процесі радянізації Західних областей УРСР (1939-1941) . . . . . . . . . . . . . 26

Лук'янченко Світлана. Агропромисловий комплекс Рівненської області

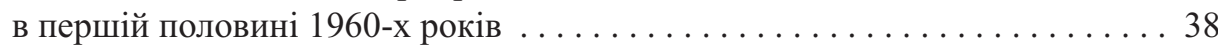

До 100-річчя ЗУНР................................ 46

Дацків Ігор. Діяльність зовнішньополітичної служби

Західноукраїнської Народної Республіки в 1918-1923 роках . . . . . . . . . 46

Королько Андрій. Становлення і функціонування органів

української влади на Снятинщині періоду ЗУНР (1918-1919) . . . . . . . . 54

Пірко Марія. Видавничі проекти державного секретаріату ЗУНР . . . . . . . . 79

Ткачук Павло, Кривизюк Леонід. Участь польових духівників у життєдіяльності збройних сил ЗУНР. . . . . . . . . . . . . 88

Пагіря Олександр. ЗУНР і національно-визвольний рух на Закарпатті в 1918-1919 роках. ................................ 100

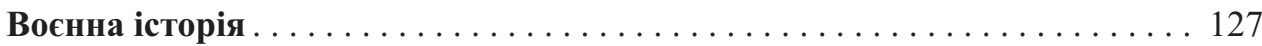

Ткачук Андрій. Політика безпеки в коаліційній угоді депутатських фракцій у Верховній раді України $\mathrm{V}$ скликання . . . . . . . 127

Попко Сергій. Державна програма співробітництва України з НАТО на 2001-2004 роки: пріоритети та завдання у контексті євроатлантичної інтеграції. . . . . . . . . . . . . . . . . . 137

Постаті .......................................... 145

Сова Андрій. Внесок Івана Боберського в підготовку та проведення

Шевченківського здвигу 1914 року у Львові . . . . . . . . . . . . . 145

Патер Іван. Суспільно-політичні процеси в Галичині 1919-1920 року в оцінці Євгена Чикаленка (за матеріалами «Щоденника») . . . . . . . . . . . 156

Соляр Ігор. Дмитро Левицький у визвольних змаганнях українців у $1914-1923$ роках. ............................... 170 
Середюк Марія. Громадсько-політична діяльність Володимира Целевича в роки національно-визвольних змагань (1918-1923) . . . . . . . . . . . . 181

Каменцев Денис. «Мене завжди тішило й почасти дивувала та велика напружена праця, яку переводять наші вояки...»: роль Володимира Сальського в організації української військової еміграції (1921-1940) . . . . . . . . . . . . . . . . . . . . . . . . . . . . 190

Кравець Наталія. Національно-культурна діяльність Василя Проходи в таборах військовополонених у роки Першої світової війни . . . . . . . . . 203

\section{МОВОЗНАВСТВО}

Осінчук Юрій. Лексика на позначення Божих Осіб, святих і ангелів в українському історичному словнику за редакцією Євгена Тимченка. . . . . 213

Bahniuk Nataliya. Researching written monuments in the context

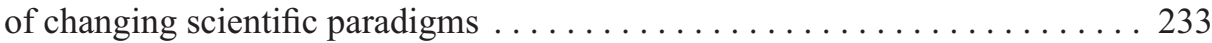

Черевко Ірина. Здобутки української діалектної фразеографії ХХІ століття . . . . . . . . . . . . . . . . . . . . . . . . . . . . 240

\section{ЛІТЕРАТУРОЗНАВСТВО}

Гаврилів Тимофій. Ідентичнісні імплікації: «3 країни рижу та опію» Софії Яблонської-Уден . . . . . . . . . . . . . . . . . . . . . . . . . . . . 251

Когут Софія. Видавничі стратегії Михайла Рудницького міжвоєнного періоду: ідеї, проекти, перспективи . . . . . . . . . . . . . . . 267

Рутар Христина. Мандрівка до (своєї) пам’яті: міжвоєнний Львів і Львів у часі Другої світової війни в сучасному українському тексті (на матеріалі романів «Музей покинутих секретів» Оксани Забужко й «Танго смерті» Юрія Винничука) . . . . . . . . . . . . . . . . . . 278

\section{ОГЛЯДИ ТА РЕЦЕНЗЇ̈}

Лановик Мар'яна. [Рец.]: «Пов'язати розгублені кінці життя і мистецтва» [на]: Мочернюк Н. Поза контекстом: Інтермедіальні стратегії літературної творчості українських письменників-художників міжвоєння: монографія. Львів: Вид-во Львівської політехніки, 2018. 392 с. + 16 кольор. вкл. . . . . . 286

Романюк Михайло. [Рец. на]: Сова А., Тимчак Я. Іван Боберський основоположник української тіловиховної і спортової традиції / за наук. ред. Євгена Приступи. Львів: ЛДУФК, Апріорі, 2017. 232 с. . . . . 295

Yastremska Tetiana. Dialectological studies: history, topics, structure . . . . . . 300 